\title{
The Azuaje travertine: an example of aragonite deposition in a recent volcanic setting, N Gran Canaria Island, Spain
}

\author{
A. Rodríguez-Berriguete ${ }^{\text {a,* }}$, A.M. Alonso-Zarza ${ }^{\text {a,b }}$, M.C. Cabrera ${ }^{\mathrm{c}}$, A. Rodriguez-Gonzalez ${ }^{\mathrm{c}}$ \\ a Dpto. Petrología y Geoquímica, Facultad de Ciencias Geológicas. Universidad Complutense de Madrid. José Antonio Nováis 2, 28040 Madrid, Spain \\ b Instituto de Geociencias (CSIC-UCM), José Antonio Nováis 2, 28040 Madrid, Spain \\ ' Dpto. Fisica GEOVOL, Campus de Tafira, Universidad de Las Palmas de Gran Canaria, 35017 Las Palmas de Gran Canaria, Spain
}

\section{Keywords:}

Travertine

Aragonite

Volcanic settings

$\mathrm{CO}_{2}$ degassing

Canary Islands

Perched systems

\begin{abstract}
A B S T R A C T
The Azuaje ravertines in the north of Gran Canary Island crop out in the Azuaje Gorge, which is incised into Miocene volcanic breccias of the Roque Nublo Formation. This travertine is interesting because of the scarcity of travertines in the Canary Islands and its close relationship with recent volcanic events. Part of the travertine overlies a lava flow, dated at $2420 \pm 40$ years BP. The travertine is composed mainly of aragonite in both perched systems on the gorge walls and in gorge bottom deposits parallel to the present stream. Perched systems include deposits from the feeder conduits within the Roque Nublo Formation that spilled out through waterfalls and over barriers. The gorge (valley) bottom system includes barrier and pool deposits. The main laminated facies are composed mostly of large fibrous aragonite crystals, while there are also common micritic and porous microfabrics. Shrubs, coated grains, coated bubbles and rafts are present in many of the deposits. Detailed study of the microfacies shows the presence of sparsely distributed biogenic features. The $\delta^{13} \mathrm{C}$ values are between +4.0 and $+11.0 \%$, and the $\delta^{18} \mathrm{O}$ values range between -11.0 and $-2.0 \%$ VPDB. These ${ }^{13} \mathrm{C}$ values lie within the range of those of thermogene travertines fed by thermal waters that cooled downstream, as indicated by the increase of the carbon and oxygen isotope values in that direction. The common occurrence of fibrous radial fabrics is interpreted to be due to disequilibrium conditions during aragonite precipitation. Disequilibrium was likely caused by rapid $\mathrm{CO}_{2}$ degassing of the thermal waters that led to a rapid increase in the degree of aragonite saturation. Thus, the morphology of the aragonite crystals and the isotopic composition indicate that the formation of the Azuaje travertine was mostly due to abiogenic processes induced by rapid degassing of thermal waters, linked to the presence of a recent lava flow within the Gorge. In short, the Azuaje traverine shows the important role of volcanic activity in travertine deposition, in the facies distribution as well as in the geochemical signatures of the deposits, and so can be used as a recent analogue for ancient travertine deposits in volcanic settings.
\end{abstract}

\section{Introduction}

Calcareous spring deposits are found in many geological settings, such as the very ancient Paleoproterozoic rift basins of the Pechenga Greenstone Belt of the Kola Peninsula, Russia (Melezhilk and Fallick, 2001), active rift systems such as the Kenya Rift Valley (Renaut and Jones, 1997), volcanic areas in Iceland (Pentecost, 2012) or in the local fault systems where groundwater discharges at the surface (Szulc et al., 2006). The criteria used to classify spring deposits include: fabric, geochemistry, morphology, biotic content, water temperature or source of the $\mathrm{CO}_{2}$, which has given rise to an extensive literature with a variety of terms that are very commonly confusing (Ford and Pedley, 1996; Pentecost, 2005; Gandin and Capezzuoli, 2008). At present there are two main classification criteria: temperature

\footnotetext{
* Corresponding author.

E-mail addresses: arberriguete@pdi.ucm.es (A. Rodríguez-Berriguete), alonsoza@geo.ucm.es (A.M. Alonso-Zarza),mcabrera@dfis.ulpgc.es (M.C.Cabrera), arodriguez@proyinves.ulpgc.es (A. Rodriguez-Gonzalez).
}

and type of water. If temperature is used as the main criterion, "tufas" are defined as a product of $\mathrm{CaCO}_{3}$ precipitation under cool water conditions (nearly ambient temperatures), and therefore contain a variety of biogenic components such as microphytes and macrophytes, invertebrates and bacteria. The term "ravertine", in contrast, is used for hard crystalline deposits lacking macrophytes or invertebrates that formed mainly from hydrothermal waters (Ford and Pedley, 1996; Pedley et al., 2003). If the source of $\mathrm{CO}_{2}$ dissolved in the water is used as the main criterion, the term "meteogene tufa and travertine" refers to deposits formed in $\mathrm{CO}_{2}$-rich waters coming from the soil and groundwater, whereas the term "thermogene travertine" is used for deposits in which the waters come from the interaction of hot rock with $\mathrm{CO}_{2}$ rich fluids at depth (Pentecost, 1993; Viles and Pentecost, 2007).

The mineralogy of calcareous spring deposits is either calcite or aragonite, or both (Jones and Renaut, 2010). Only exceptionally in Precambrian rocks is dolomite found as a primary mineral of travertines (Melezhik and Fallick, 2001). The relatively poor mineralogical variety is accompanied by a huge variety in facies and microfacies, ranging from micritic to coarsely crystalline and from hard and dense to very 
porous and fragile facies. Mineralogy, facies and microfacies are controlled by a set of environmental parameters such as: water composition and temperature, saturation levels and the rate of $\mathrm{CO}_{2}$ degassing, macro and microbial activity or the presence of some inhibitors (Jones and Renaut, 2010). Spring deposits can also provide useful paleoenvironmental information on paleohydrology, paleoclimatology, paleovegetation or neotectonics (Hankock et al., 1999; Andrews, 2006; Anzalone et al., 2007; Keppel et al., 2011).

Despite calcareous spring deposits have been reported in volcanic settings (D'alessandro et al., 2007), they are very rarely described in the Canary Islands (Demény et al., 2010), which are formed mostly by volcanic rocks. The Azuaje Gorge, in the north of Gran Canary Island (Fig. 1), records important Holocene volcanic and sedimentary events. One of the most striling features is the presence of calcareous spring deposits (Azuaje travertine) at different elevations along the gorge walls, and stratigraphically above an intra-canyon Holocene basaltic lava flow. The gorge is entrenched in volcanic rocks, so that the variety, complexity and mineralogy of the facies of the Azuaje travertine make it important as an aid to the understanding of the processes and the main controls involved in the formation of travertines in volcanic settings and their paleoenvironmental and paleohydrological significance.

\section{Geological setting}

The Canary Islands comprise seven main islands and several islets situated in the Atlantic Ocean, between $29^{\circ} 25^{\prime}$ and $27^{\circ} 37^{\prime} \mathrm{N}$ and $18^{\circ}$ $10^{\prime}$ and $13^{\circ} 20^{\prime} \mathrm{W}$ (Fig. 1). These islands developed in a geodynamic setting characterized by a thick, rigid and old (Jurassic) oceanic lithosphere lying close to a passive continental margin on a slow-moving plate (the African plate). The spatial and chronological evolution of the Canaria volcanism, from east to west, is due to the progression of the African plate over a mantle plume (Carracedo et al., 2002). In common with other intra-plate volcanic islands, the Canaria archipelago displays the typical stages of volcanic hotspot evolution: a stage of submarine and subaerial growth (the latter one divided between a juvenile (shield) stage, a volcanic quiescent stage, and a stage of rejuvenation).

Gran Canaria Island, in the central part of Canary Islands (Fig. 1), is nearly circular in shape and about $45 \mathrm{~km}$ in diameter, and has an altitude of $1949 \mathrm{~m}$ a.s.l. at the center of the island (Pico de Las Nieves). A dense radial network of deep ravines (known locally as "barrancos") dissects the island, forming a rugged topography, with mean slope values of up to $15^{\circ}$. The altitude is key to understanding the island climatic zones: a humid northern part is buffeted by storms from the Azores Anticyclone, whereas a dry southem part receives little precipitation (Menéndez et al., 2008). The rocks outcropping in Gran Canaria are all of subaerial origin. Gran Canaria can be classified as a volcanic island in an advanced rejuvenated stage (e.g., Carracedo et al., 2002; Guillou et al., 2004; Menéndez et al., 2008). The geological evolution of Gran Canaria records the three main stages of subaerial growth: a juvenile stage (ca. 14.5-8.0 Ma, including a basaltic shield volcano, a vertical caldera collapse and a salic post-caldera resurgence); a volcanic quiescent stage (ca. 8.0-5.5 Ma, including the most prominent sedimentary deposits the Las Palmas Detritic Formation); and a rejuvenated stage (ca. 5.5 Ma to present, including the Roque Nublo strato-volcano and the Post Roque Nublo volcanism). The most recent volcanic activity of Holocene age and belonging to the Post Roque Nublo volcanism is geographically restricted to the northern half of the island. The distinctive feature of these Holocene eruptions is the emplacement of the lava flows along the bottom of the ravines (Rodriguez-Gonzalez et al., 2012). One of these Holocene volcanic events generated an eruptive fissure located at the NE flank of the Pleistocene Montaña Doramas cone, from which a lava channel flowed more than $6 \mathrm{~km}$ along the bottom of the Azuaje Gorge in the NE of the island. This eruption has been radiocarbon dated at $2420 \pm 40$ years BP (Rodriguez-Gonzalez et al., 2009).

The Azuaje carbonate deposits are situated within the "barranco" (Fig. 1). The Gorge has been incised into rocks dating from the rejuvenated stage, under a subtropical to temperate humid climate; precipitation rates exceed $1000 \mathrm{~mm} /$ year at its headwaters (Menéndez et al., 2008). It is one of the longest ravines in the island $(19.6 \mathrm{~lm})$, with an altitude of $1640 \mathrm{~m}$ at its head (Menéndez et al., 2008).

These carbonate deposits crop out for a few meters in small patches at different levels, mainly on the canyon walls, over $1 \mathrm{~km}$ extent in the middle of the ravine (Fig. 2). In outcrop, the carbonates seem to be younger than the Holocene lava flow from the Montaña Doramas eruptive fissure.

\section{Methods}

Fourteen carbonate samples were selected from representative facies. Conventional optical petrography studies were performed on 15 thin sections. The more fragile samples were coated with an epoxy

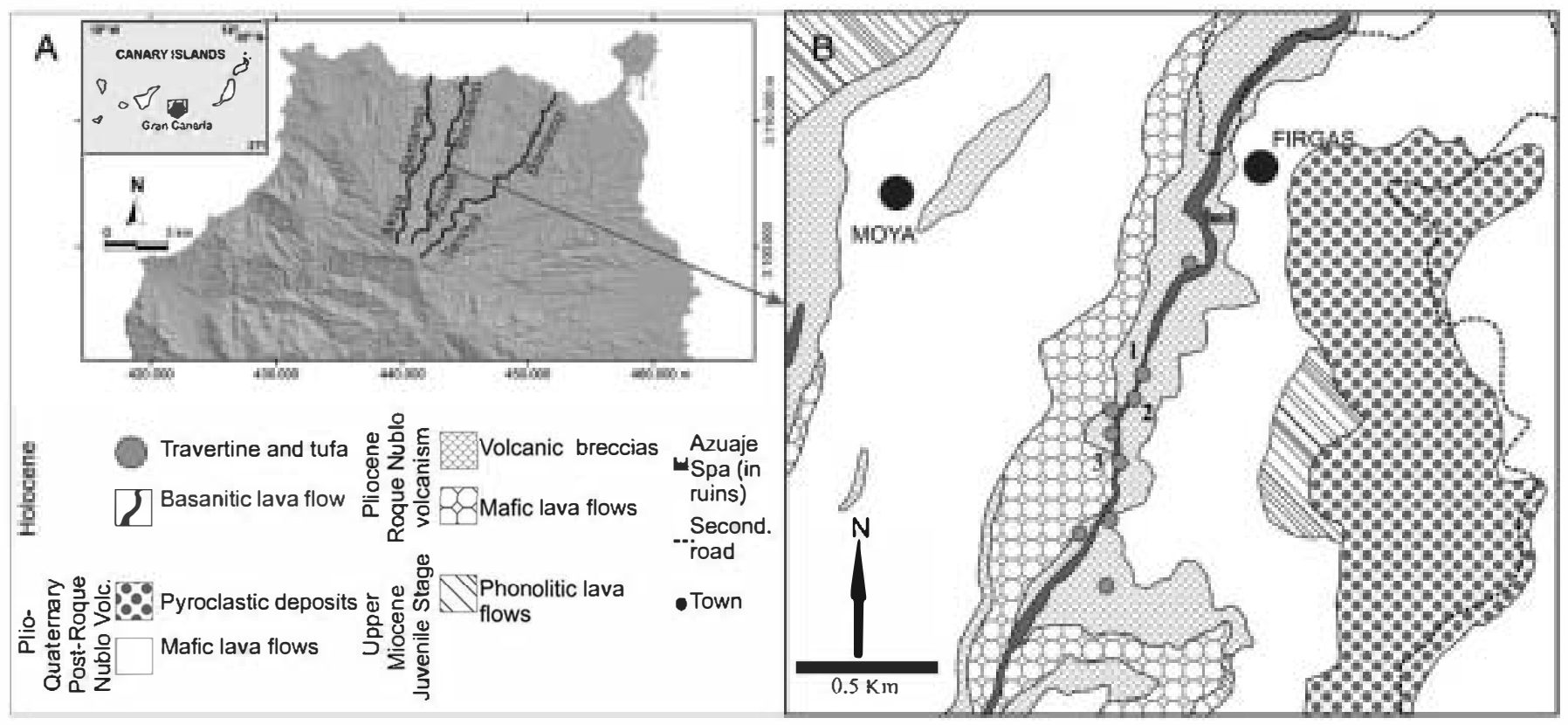

Fig. 1. A: Location of the Azuaje Gorge on Gran Canaria Island. B: Geology of the Azuaje Gorge showing the locations of the travertine outcrops. 
resin. An Olympus BX51 optical microscope with an Olympus U-TVO.5XC-3 camera was used for the study. Sixteen powdered samples from selected facies were mineralogically characterized using a Phillips PW-1710 X-ray diffraction (XRD) system operating at $40 \mathrm{kV}$ and $30 \mathrm{~mA}$, under monochromate $\mathrm{CuK} \alpha$ radiation.

Scanning electron microscopy was performed on five gold-coated samples. Observations were made using a JEOL JSM 6400 electron microscope working at $20 \mathrm{kV}$, with a resolution of $35 \dot{A}$. Secondary electron and backscattering detectors were used together with an $\mathrm{X}$-ray detector system to obtain semi-quantitative compositions. Field emission electronic microscopy (FEM) were also performed on two samples using a JEOL JSM 6335F working at $10 \mathrm{kV}$.

The $\delta^{13} \mathrm{C}$ and $\delta^{18} \mathrm{O}$ values from these powdered samples were obtained by the Scientific and Technical Survey, Barcelona University (Spain). Samples were washed with $100 \%$ phosphoric acid at $70{ }^{\circ} \mathrm{C}$ for 3 minutes. The $\mathrm{CO}_{2}$ was extracted using a Thermo Finnigan Carbonate Kiel Device III isotopic analyzer with a Thermo Finnigan MAT-252 spectrometer, according to the McCrea (1950) method. Values obtained were corrected using the NBS-19 standard. Results were expressed on $\delta$ notation in parts per thousand (\%) referred to VPDB standard. Reproducibilities obtained were better than $0.03 \%$ for $\delta^{13} \mathrm{C}$ and $0.05 \%$ for $\delta^{18} \mathrm{O}$.

The two samples with highest aragonite relative to calcite content were selected for radiocarbon dating. Beta Analytics Inc. (Miami, Florida, USA) analyzed the samples with an accelerated mass spectrometer (AMS), following the standard procedures of that laboratory. The final results were corrected using a predetermined ${ }^{13} \mathrm{C}$ correction of $-5 \%$. No conversion to calendar age was made.

\section{Description of the Azuaje Carbonate Deposit}

\subsection{Location of the carbonate deposits}

The carbonate deposits from Azuaje consist of many small outcrops with carbonates developed on the Roque Nublo volcanic breccia and on the Holocene lava flow. The travertine outcrops are perched at different heights in the gorge, or also occur parallel to the stream. The outcrops are distributed along $1 \mathrm{~km}$ in the middle course of Azuaje Gorge.

The original travertine was partially modified as a result of natural erosion and destroyed by quarrying to obtain lime. As a consequence the outcrops are no longer contiguous. Three major outcrops (Fig. 1) were studied, all situated upstream from the Azuaje Spa building (Fig. 1), which is in ruins. Outcrop 1 is on the right margin of the present stream (Fig. 1). It is a complex outcrop in which the carbonates are perched or hanging above the valley bottom. Outcrop 2 consists of filled fractures and well-laminated deposits only a few meters from the present river. Part of the outcrop covers materials from a lava bubble

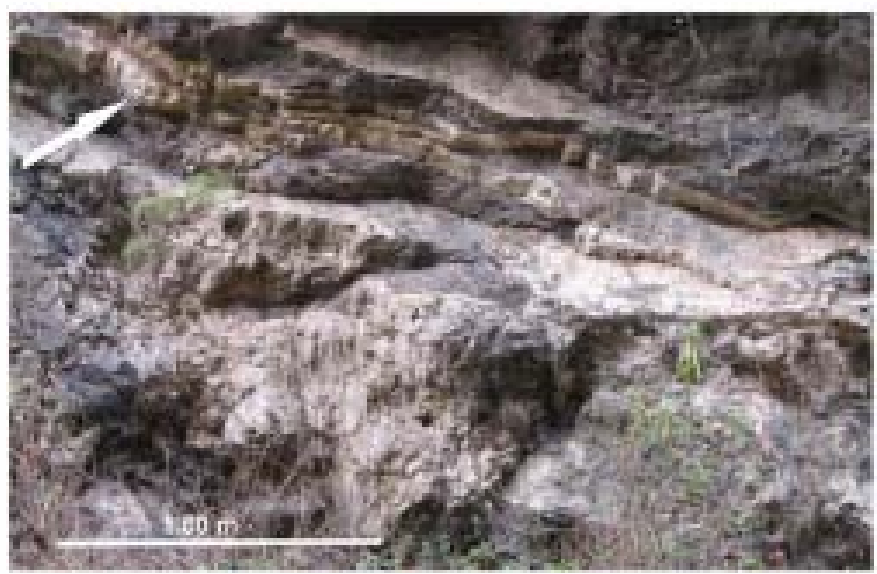

Fig. 2. Tabular aragonitic laminated crusts cutting the volcanic Roque Nublo Formation (Outcrop 3). These are interpreted as the feeder conduits of the system. produced during the flow and subsequent cooling of the Holocene lava (Rodriguez-Gonzalez et al., 2009). Outcrop 3 is further upstream than the other outcrops, on the left side of the stream. This is the largest and best preserved highly contiguous outcrop.

\subsection{Morpho-depositional systems}

The general arrangement and facies of the spring deposits of Azuaje Gorge allows recognition of two main types of morpho-depositional systems (Table 1): (1) perched systems on gorge walls, and (2) gorge bottom systems deposited parallel to the present stream (Ford and Pedley, 1996; Sanders et al., 2011).

\subsubsection{Perched systems}

The deposits of perched systems are found at different levels along the gorge walls. The dimensions of the preserved carbonate bodies are small, with a maximum height of $10 \mathrm{~m}$ and width of about $20 \mathrm{~m}$. These systems drape over the Roque Nublo volcanic breccias. Outcrops of the perched systems consist of:

Tabular crusts crossing the host rock (Fig. 2), a few centimeters thick, internally laminated, vary from planar to wavy lamination. Many of the crusts, which have a horizontal to sub-horizontal geometry, grow from the inner part of the host rock through a discontinuity. The crusts partially displace and open an initial discontinuity while also replacing and filling (cement) the previous porosity of the host rock. They are composed of aragonite laminae ranging from 1 to $5 \mathrm{~mm}$ thick. These crusts were the precipitates within the fluid conduits through the aquifer, and so are deposits of the feeder channels of the spring system that at different points reached the surface and spilled out into the valley. Similar deposits have been referred to as vent deposits (Fouke et al., 2000) or spring-stones (Sanders et al., 2011).

Vertical carbonate deposits consist of columnar and spindle-shaped bodies pointing downwards (Fig. 3A, B). These bodies hang from a main spring outlet situated within the volcanic host rock, and normally occur on very steep walls. The columns are a few metres long, $\mathrm{cm}$ to $\mathrm{dm}$ in diameter and show internal concentric banding or lamination. In hand samples the porosity is highly varied; some samples show mm-sized pores, but in others the porosity is not visible. These deposits stem from waterfalls (Pentecost, 2005) situated at different heights in the ravine.

Stepped and sloped carbonate deposits follow the original topography of the walls, but their slope can also be the result of carbonate sedimentation. Contact between the carbonate and volcanic substrate is

Table 1

Classification of the Azuaje travertine deposits and their main microfacies.

\begin{tabular}{lll}
\hline System & Subsystem/geometry & Microfacies \\
\hline $\begin{array}{l}\text { Perched } \\
\text { (P) }\end{array}$ & tabular crusts & laminar coarse \\
& (feeder conducts) & crystalline \\
& vertical & laminar fibrous \\
(waterfall) & laminar micritic \\
& stepped and sloped & laminar fibrous, \\
& (terrace pools and cascades) & laminar micritic, \\
& & shrubs, rafts \\
& & coated bubbles \\
& rafts \\
horge bottom & micritic \\
(GB) & coated bubbles \\
& stepped and sloped & laminar fibrous, \\
& (terrace pools and cascades) & laminar micritic, \\
& & coated grains, \\
& & shrubs, rafts, \\
& & coated bubbles \\
\hline
\end{tabular}


gradual as the unaltered substrate passes into partially-cemented substrate and/or is replaced by carbonates, and then finally into carbonate with a few volanic fagments. Facies observed are mainly laminated with high porosity (Fig. 3A, B). The morphology of these carbonate deposits strongly suggests that they originated as barriers and/or prograding cascades, but also as sloping laminae, similar to those commonly described in many perched carbonate deposits, such as those found in Quaternary examples of the Granada Basin (Martin-Algarra et al., 2003), in the Alps (Sanders et al., 2011) or in SW Japan (Kano and Fuji, 2000).

\subsubsection{Gorge bottom systems or Creek systems}

Gorge bottom systems formed at or near the present bottom of Azuaje Gorge. The deposits are parallel to the present stream, but no active carbonate sedimentation was observed. These systems can be found on different slope gradients (Pentecost, 2005) and include (a) stepped and sloped deposits, and (b) horizontal to sub-horizontal deposits (fluvial crusts of Pentecost, 2005).

Stepped and slopped deposits occur on gentle slopes following the topography. These carbonate deposits show aggrading and prograding geometries. The laminated bed on an initial low-angle slope can be covered by a bed deposited on top. Progressive deposition can alter the angles of slope of the travertine deposit and its laminae both positively and negatively (Fig. 4). Evolution from high- to low-angle bedding is also seen, and is the result of migration at the sites of successive barriers and/or prograding cascades situated along the stream (Vázquez-Urbez et al., 2012).

Horizontal-subhorizontal deposits show the largest lateral continuity and are found a few metres above the present riverbed, occurring behind the mounds of slope deposits. In the field these deposits are well-laminated (Fig. 4). The laminae are either planar or wavy, varying from dense to very porous. Some massive porous deposits lacking lamination also occur. Acicular and botryoidal cements occur along pore walls. Where the deposits directly overlie the riverbed, the initial carbonate deposits encrust the weathered volcanic rocks or a sedimentary breccia of volcanic fragments. These deposits form in the pool and/or ponded areas of the outflow system (Pentecost, 2005; Vázquez-Urbez et al., 2012).

\subsection{Microfacies: petrography and their related environments}

Here we describe the facies and microfacies found in the Azuaje deposits. The facies are described independently of their occurrence within the different morpho-depositional system because many of them occur in differing situations (Table 1). In general, the dominant phase is aragonite in proportions higher than $50 \%$, with calcite in variable amounts and traces of phyllosilicates (Table 2) and very low amounts of quartz.

The laminar coarsely crystalline microfacies is the only component of the tabular crusts, and is formed by fibrous aragonite crystals ( $>4 \mathrm{~mm}$ ) oriented either with their long axis perpendicular to the crust or in fan-like arrangements which cut the lamination. The lamination (mm-scale) is relatively regular (Fig. 5A), and is due to the presence of thin opaque laminae that alternate with transparent and thicker reflective laminae. The aragonite crystals are longer than the thickness of the individual laminae, thus some of them cut or cross the laminations. Crystal width increases from the basal contact with the host rock towards the inner part of the crist. These microfacies, which are very similar to sparitic speleothems (Frisia and Borsato, 2010), occur in crusts within the host rock or in older carbonate. They lack biogenic features. We interpret them as aragonite precipitates of abiotic origin, as described also by Sanders et al. (2011), formed mostly by cementation. The lamination is due to variability of the flow rate within the feeder channel.

Laminar fibrous microfacies occur as (1) brown bands containing dark-light lamination (Fig. 5B) and fibrous-radial spherulites, and (2) light bands containing dark laminae. The bands, about 70-400 $\mu \mathrm{m}$ thick, are adapted to the morphology of their substrate. The brown bands contain light laminae $(4 \mu \mathrm{m})$ formed by normal to radial aragonite fibers, that alternate with thin $(1 \mu \mathrm{m})$ dark, micritic laminae. Dark micritic laminae are irregular and in some cases the micrite seems
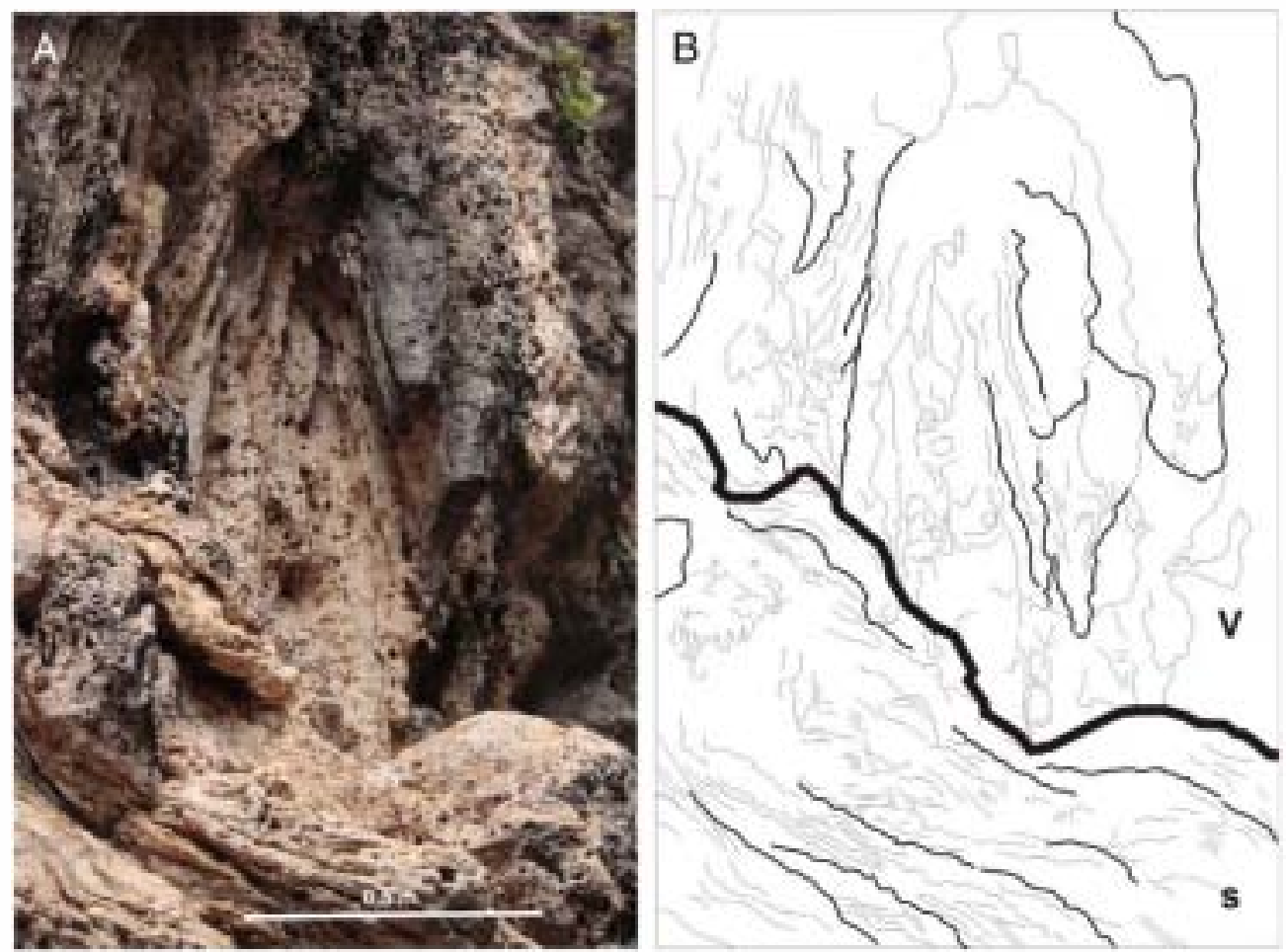

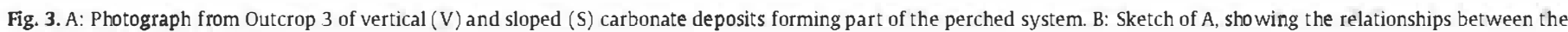
vertical and the slope deposits. 


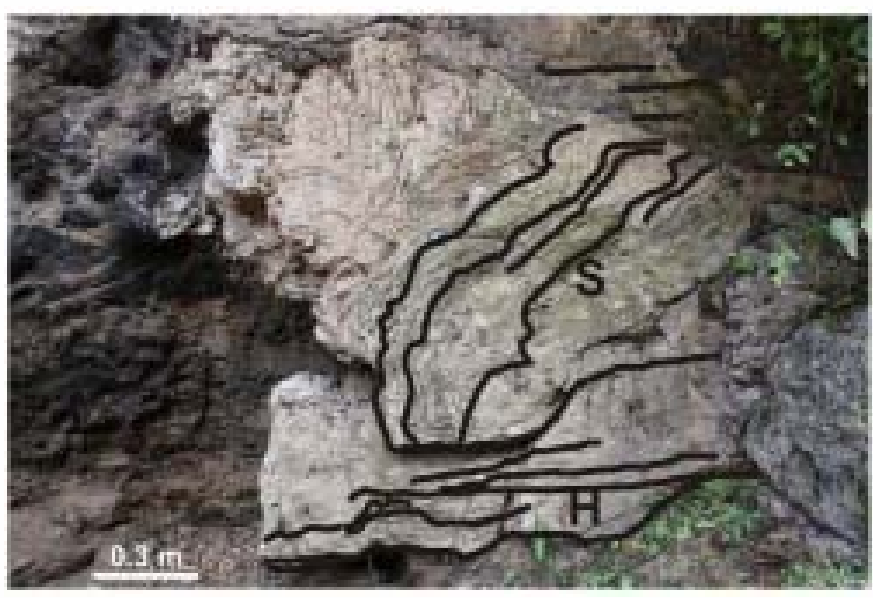

Fig. 4. Gorge bottom system composed of horizontally bedded (H) slope deposits (S), which are well laminated (Outcrop 2). The image shows the evolution from pond to sloping small barrier sediments.

to corrode the aragonite fibers. Light bands are about $0.5 \mathrm{~mm}$ thick and consist of fibrous to acicular calcite or aragonite crystals, cut by some thin micritic dark lamina. The calcitecrystals include relics of aragonite fibers. SEM images (Fig. SC) show that the coarse fibrous aragonite crystals lack biogenic features, although some of them have dissolution features. Within the micritic laminae that are intercalated with fibrous laminae, some mucilaginous films and diatoms are observed. This microfabric can be included within the term "crystalline ravertine" (Jones and Renaut, 2010). The fibrous aragonite crystals from the brown band were probably formed under normal (probably high) flow conditions, and represent primary deposits. Similar deposits have been interpreted as biogenic and so could be similar to stromatolites (Zamarreño et al., 1997; Freytet and Verrecchia, 1998), but also could have been produced by inorganic precipitation (Valero-Garcés et al., 2001) or even from diagenetic processes under phreatic conditions (Ostermann et al., 2007). In our case, both thin section and SEM studies do not show many biogenic features, so most of the initial aragonite precipitation was probably inorganic. However, biofilms could have acted as templates for the nucleation. The thinner micrite bands imply a decrease in the precipitation rate, which could have caused the partial dissolution or micritization of the previous crystals to form micrite, as described in speleotherns (Martin-Garcia et al., 2009). The light coarse

Table 2

Mineralogy and isotope values of the studied samples. P: perched system; Gb: Gorge bottom system.

\begin{tabular}{|c|c|c|c|c|c|c|}
\hline Sample & System & Aragonite & Calcite & Phyllo. & $\delta^{13} \mathrm{C}(\mathrm{PDB})$ & $\delta^{12} \mathrm{O}(\mathrm{PDB})$ \\
\hline \multicolumn{7}{|l|}{ Outcrop 1} \\
\hline$A 21 \mathrm{~A}$ & $P$ & 90 & 10 & 0 & 9.03 & -3.09 \\
\hline$A 21 C$ & $\mathrm{P}$ & 85 & 10 & 5 & 9.24 & -2.84 \\
\hline$A 22 A$ & $\mathrm{P}$ & 75 & 15 & 10 & 10.22 & -2.08 \\
\hline$A 23 A$ & $P$ & 95 & 5 & 0 & 10.78 & -4.74 \\
\hline$A Z 4 A$ & GB & 55 & 40 & 5 & 8.79 & -4.82 \\
\hline$A Z 4 B$ & GB & 80 & 20 & 0 & 10.06 & -4.26 \\
\hline$A 25 A$ & GB & 45 & 45 & 10 & 8.53 & -4.63 \\
\hline$A Z 6 A$ & GB & 50 & 50 & 0 & 5.59 & -5.32 \\
\hline$A 26 B$ & GB & 40 & 60 & 0 & 3.96 & -7.93 \\
\hline \multicolumn{7}{|l|}{ Outcrop 2} \\
\hline$A 28 \mathrm{~A}$ & GB & 45 & 55 & 0 & 5.48 & -8.80 \\
\hline$A Z 9 A$ & GB & 55 & 45 & 0 & 6.75 & -5.31 \\
\hline $\mathrm{A} 210 \mathrm{~A}$ & GB & 60 & 35 & 5 & 6.02 & -7.16 \\
\hline A2 $13 \mathrm{~A}$ & GB & 95 & 5 & 0 & 7.58 & -7.27 \\
\hline \multicolumn{7}{|l|}{ Outcrop 3} \\
\hline$A 215 A$ & $\mathrm{P}$ & 75 & 25 & 0 & 5.35 & -8.71 \\
\hline A2 $16 \mathrm{~A}$ & $\mathrm{P}$ & 95 & 5 & 0 & 4.12 & -11.32 \\
\hline$A 217 \mathrm{~A}$ & GB & 10 & 90 & 0 & 4.32 & -5.39 \\
\hline
\end{tabular}

bands, containing more calcite, probably represent a neomorphic product, including inversion and crystal aggradation of the initial aragonite fibers. Both micritization and neomorphism indicate that these facies underwent rapid diagenesis.

Laminar micritic microfabric consists of $70-400 \mu \mathrm{m}$ thick laminae of varying porosity composed of micrite. The lamination is irregular and drapes the morphology of the substrate. Some calcified micritic filaments and coarse microspar crystals are seen under FEM (Fig. 5D).

Shrubs are bush-like bodies ranging from less than $1 \mathrm{~mm}$ to $3 \mathrm{~mm}$ high, formed by fibrous aragonite crystals (Fig. 6A). In some cases shrubs are composed of calcite crystals with undulating extinction and an overall dendritic morphology with radially arranged fibrous-like opaque inclusions (Fig. 6B). There is no clear agreement on the origin of these microfabrics, as there are arguments in favor of biogenic (Chafetz and Folk, 1984; Chafetz and Guidry, 1999) and abiogenic (Jones and Renaut, 1995) origins. In addition, the presence of some calcite shrubs also suggests neomorphism and cementation processes. The shrub facies are typically located at terrace pools and depressions, similarly to those described by Guo and Riding (1998).

Coated bubbles (Schreiber et al., 1981; Guo and Riding, 1998) were found both in micritic and sparitic matrix (Fig. 7A). Bubbles consist of 0.1 to $2.0 \mathrm{~mm}$ diameter hollows surrounded by micritic and fibrous to acicular or even prismatic rings (Fig. 7A, B). Total thickness of the coating of the largest bubbles is about $400 \mu \mathrm{m}$. The genesis of coated bubbles has been explained as biogenic due to microbial activity in bacterial mats (Chafetz and Folk, 1984), but also due to abiogenic processes such as $\mathrm{CO}_{2}$ release (Chafetz and Folk, 1984; Jones and Renaut, 2010) or by the dynamics of the stream itself that can produce bubbles in waterfalls and associated pools (Chafetz et al., 1991).

Rafts are micritic platelets (Fig. 7C) with lengths of a few centimeters and thicknesses ranging from $80 \mu \mathrm{m}$ to $200 \mu \mathrm{m}$. They are covered mainly on their lower side by crystals and crystal aggregates (fans, spherulites) which can reach even millimetric length (Fig. 7D). Crystals are mainly fibrous to acicular aragonite, but also equi-dimensional subhedral calcite occurs. Rafts formed at the water-air interface and subsequently sunk and accumulated at the bottom of pools with still to very slow flowing waters (Jones and Renaut, 2010). Rafts have been described in both caves and rivers (Taylor et al, 2004).

Coated grains. This microfacies consists of grains with diameters of $100 \mu \mathrm{m}$ to $1 \mathrm{~cm}$, showing coarsening upward trends (Fig. 8A). There are two main types of grains, the first consisting of a micritic nucleus enveloped by regular concentric laminae (Fig. 8B). In many cases the nuclei are dissolved. In the second type the laminae are mammillated and formed by fibrous aragonite and aragonite shrubs in the external envelopes (Fig. 8C). The second type contains many diatoms (Fig. 8D). Coated grains similar to those described here are commonly found in pools with periodic disturbances. Their origin is debatable. Some authors consider that they are due to microbial activity (Chafetz and Meredith, 1983; Jones, 2009; Jones and Renaut, 2010), whereas an abiotic origin of precipitation from supersaturated waters in pools has also been invoked (Nader, 2007).

Porous microfabrics consist mostly of micrite incrustations around plant molds (leaves and stems). The plant molds are either preserved or dissolved, leaving an irregular $\mathrm{mm}$ - to $\mathrm{cm}$ - sized porosity. The micrite is composed of a network of filaments embedded in calcite or aragonite cements. Sandy to silty detrital grains of micrite and volcanic fragments, as well as diatoms, are included within incrustations. Fibrous spherulites, micritic rafts ( $<2 \mathrm{~mm}$ in length) and dendritic or bush-like crystals with clear fibrous relics are also present. Coated grains of less than $5 \mathrm{~mm}$ diameter can also be present. Cements are acicular to prismatic crystals, and occur as isolated crystals or form palisades or crusts. Fe-oxides line the pore walls but also occur as spherical bodies smaller than $30 \mu \mathrm{m}$. In some cases the porous fabrics are formed by coarser aragonite/calcite crystals surrounding the plant moulds, thus forming a porous crystalline microfabric. The porous microfabrics are the deposits of pools with abundant vegetation, 

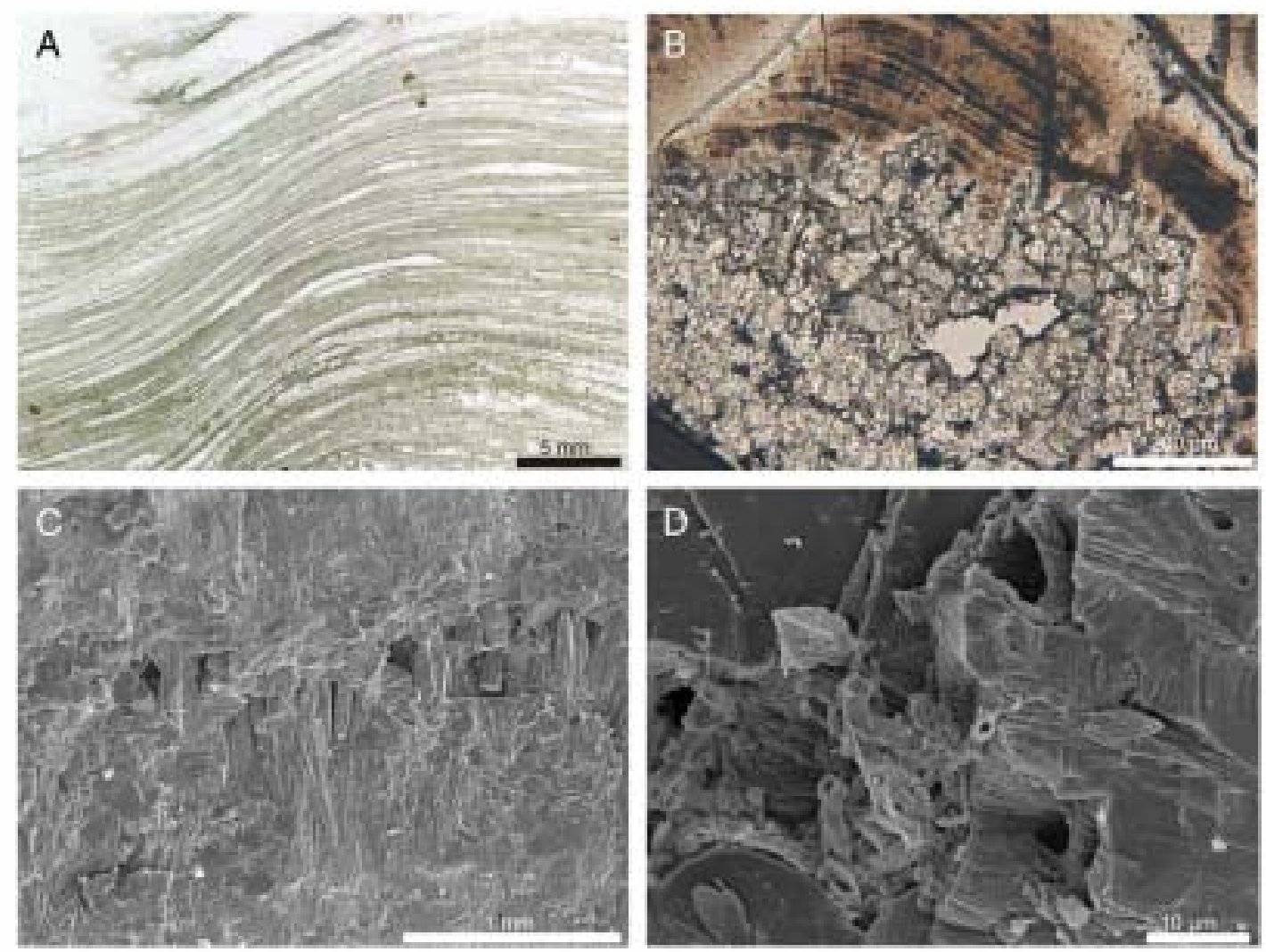

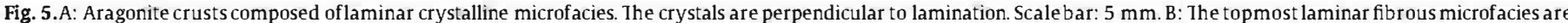

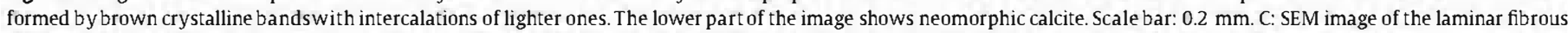
microfacies composed by aragonite fans. Scale bar: $0.2 \mathrm{~mm}$. D: Calcified micritic filaments within the porosity left by microspar calcite crystals.

and are similar to fabrics commonly described in cool-water tufas (Pedley, 1990), but they also contain aragonite elements such as shrubs that are more typical of hot-water springs outflow. Very probably this microfacies formed in the distal parts of the springs, where the hot water had cooled enough to allow colonization of the pools by higher plants. The crystalline microfabric probably formed by recrystallization and cementation of the porous micritic fabric.

\section{Stable isotopes and radiocarbon dating}

The $\delta^{13} \mathrm{C}$ and $\delta^{18} \mathrm{O}$ values obtained from selected facies show a wide range. The $\delta^{13} \mathrm{C}$ values are between +4.0 and $+11.0 \%$, and the $\delta^{18} \mathrm{O}$ values are between -11.0 and $-2.0 \%$, referring to VPDB standard. The different samples have been considered based on two main criteria: the outcrop and the aragonite content $<$ or $>70 \%$ in aragonite). Fig. 9 shows that there is a general trend to heavier values from outcrop 3 (upstream) to 1 (downstream). Within the same outcrop the samples richer in aragonite show higher carbon isotope values. The samples richest in aragonite show a good covariance trend that is less clear in samples with lower aragonite content. In Fig. 9 three trend-lines was drawn representing only aragonite-rich samples $\left(R^{2}=0.8\right)$, calcite-rich samples $\left(R^{2}=0.35\right)$ and all (calciteand aragonite-rich) samples $\left(R^{2}=0.61\right)$. In addition, the samples with less aragonite show a narrower range of oxygen isotope values.

The $\delta^{13} \mathrm{C}$ values generally increase downstream. This trend is common in carbonate waters and springs, but the increase is smaller in travertines than in spring waters (Chafetz and Iawrence, 1994; Kele et al., 2008 and 2011).

The ages obtained using the radiocarbon method are $34,470 \pm$ 290 years BP corresponding to Outcrop 1, and more than 43,500 years
BP (out of radiocarbon dating limits) in a sample from Outcrop 3 (Table 2 ). These ages disagree with the lava-carbonatestratigraphic relations observed in outcrop, assuming a lava flow age of $2,420 \pm 40$ years BP (Rodriguez-Gonzalez et al., 2009). The difference is likely due to the supply of volcanic $\mathrm{CO}_{2}$ which is "dead" and so causes error in the radiocarbon dating method (Gasparini et al., 1990).

\section{Discussion}

\subsection{Morpho-depositional and paleohydrological systems}

The Azuaje travertine deposits are an outstanding feature of the Canary Islands. Their position over a lava-flow erupted about 2500 years ago indicates that the carbonate deposits are very recent. There may have been a relationship between the volcanic event and carbonate deposition, as recorded in the smaller Berrazales deposit, which lies within a valley with Holocene volcanic activity dated at about $3 \mathrm{kyr}$ (Rodriguez-Gonzalez et al., 2009). However, there is no active carbonate deposition in either of these two areas and the recent spring activity has been strongly reduced in the last decades (Hemandez-Quesada et al., 2011).

The distribution of the carbonate outcrops within the Azuaje Gorge clearly indicates that travertine constituted a perched system (Ford and Pedley, 1996; Sanders et al., 2011) which fed the bottom of the gorge (valley), thus defining two different morpho-depositional systems: (1) perched systems on gorge walls, and (2) gorge bottom systems deposited parallel to the present stream. Groundwater circulated through the fractures and discontinuities of the Roque Nublo volcanic breccias. The carbonates then formed within the feeder channels that were the main paths of the water to their outflow in the cascades 

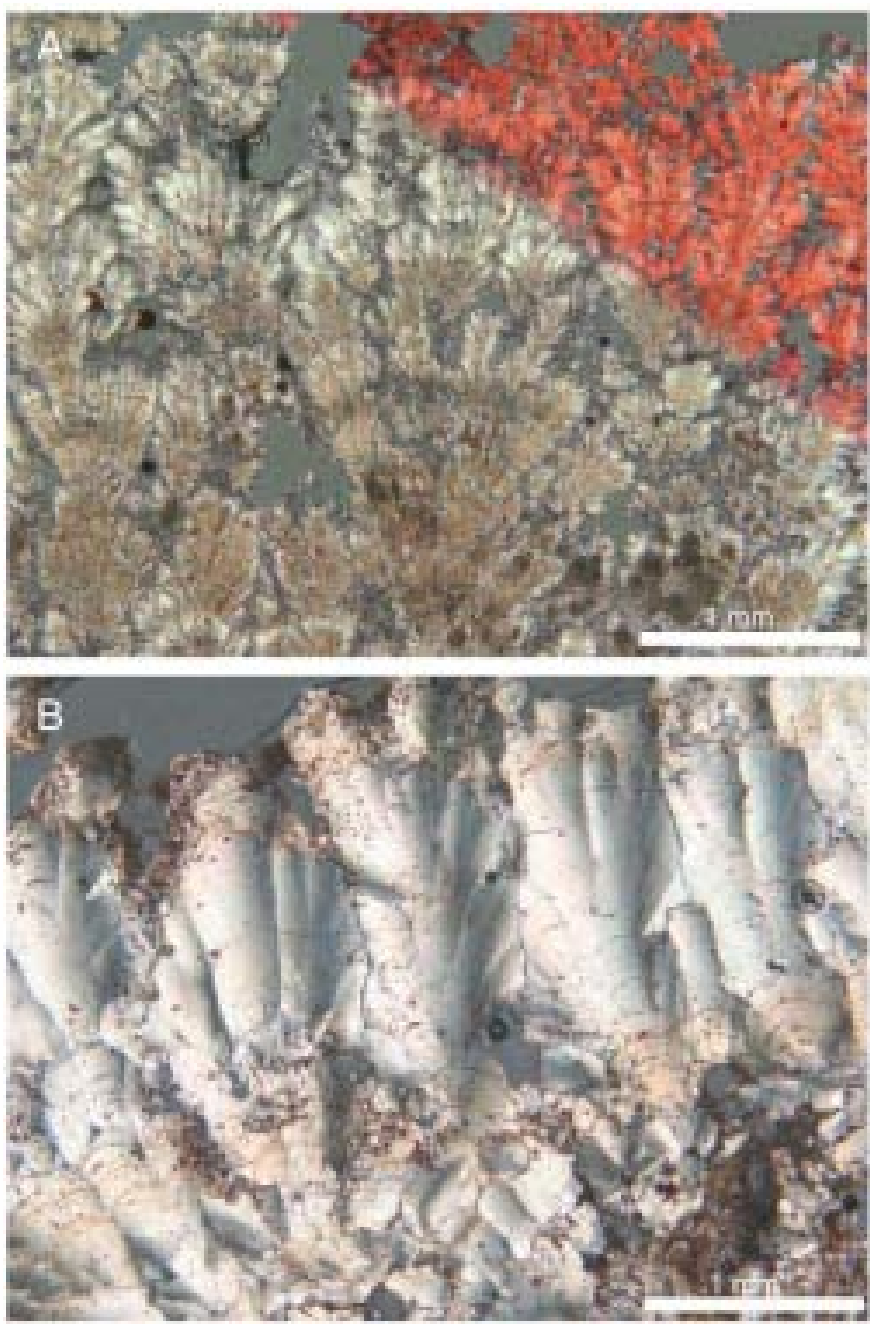

Fig. 6. A: Photomicrograph of aragonite shrubs with a high porosity between them Scale bar: $1 \mathrm{~mm}$. B: Calcite shrubs showing undulous extinction and some opaque inclusions. Scale bar: $1 \mathrm{~mm}$

of the perched systerns. The presence of carbonates at different points and levels within the gorge indicates both a phreatic level higher (near $150 \mathrm{~m}$ at their maximum point, but the heterogeneous permeability of volcanic materials outcropping must be considered) than today and also changes in the locations of the main outflows of water through the valley. This agrees with the insular aquifer hydrogeological mode: each island can be considered a unique groundwater body, recharged by rainfall infiltration and discharging into the sea along the coast, with some discharges as springs and along channels depending on lithological changes (Custodio, 2007). The study area represents the stage before the intensive exploitation of the insular aquifer, when the water-table was higher and water discharged through springs in an area where groundwater had a high input of magmatic gas.

The distribution and geometry of the facies indicate three main elements: pools, barriers and cascades. Vertical morphology with concentric lamination represents the main waterfalls feeding the system. High- to low-angle slope deposits are found along the gorge bottom and formed as small barriers and cascades. Pool facies are horizontally-stratified, laminated bodies showing vertical transitions that include coated grains, shrubs and rafts, which seem to reflect changes from high- to very low-flow to stagnant conditions. These changes may be due to short-time scale flow variations, but they may also be due to their formation in cascades or their adjacent pool upstream might have prograded at outcrop scale as a result of the morphological evolution of the system itself.

\subsection{Stable isotopes and source of $\mathrm{CO}_{2}$}

The isotopic values of the Azuaje travertine are similar to those commonly described in thermogene travertines around the world, in which the $\mathrm{CO}_{2}$ of the water is of thermal origin and proceeds from or below the Earth's crust (Pentecost, 2005). Positive $\delta^{13} \mathrm{C}$ values have been reported in travertine deposits from thermal systems in Andean lake basin (Valero-Garcés et al., 2001) and in hot-spring carbonates from many different locations (Minissale, 2004; Yoshimura et al., 2004; Pentecost, 2005; Rainey and Jones, 2009; Kele et al., 2011). The positive carbon isotopic signature seems to be characteristics of hot-springs of hydrothermal origin, or thermogene tufa or travertine (Jones and Renaut, 2010; Pentecost, 2005), suggesting an endogenous origin for the $\mathrm{CO}_{2}$ of the waters of the Azuaje travertine. Thermogene travertines are characterized by (1) positive values of ${ }^{13} \mathrm{C}$, (2) negative values of ${ }^{18} \mathrm{O}$, and (3) a covariation trend downstream with increase in both $\delta^{13} \mathrm{C}$ and $\delta^{18} \mathrm{O}$ values (Chafetz and Lawrence, 1994). These features are recognized in the Azuaje ravertine. The increase of values downstream is seen in samples with aragonite contents higher than $70 \%$.

Their carbon isotopic composition suggests progressive $\mathrm{CO}_{2}$ degassing and/or evaporation in a downstream direction. The ${ }^{13} \mathrm{C}$ values from travertines can be used to determine the origin of $\mathrm{CO}_{2}$ (Kele et al., 2003, 2011; Minissale, 2004) using the formula provided by Panichi and Torgiorgi (1976) for Italian travertines $\left({ }^{13} \mathrm{C}_{\left(\bullet_{2}\right\rangle}=1.2\right.$ $\left.\delta^{13} C_{\text {(travert.) }}-10.5\right)$. We tentatively used that equation for the Azuaje samples to obtain a range -2.8 to $+2.4 \%$, with mean values of $1.7 \%$ for the $\delta^{13} \mathrm{C}_{(\mathrm{C})\rangle}$ of the water. Expected values for $\delta^{13} \mathrm{C}_{(\mathrm{C}) 2\rangle}$ of volcanic origin range from -8 to $-6 \%$ (Mook, 2001). In the Canary Islands, direct measurements of dissolved $\mathrm{CO}_{2}$ in groundwaters from galleries range from -4.0 to $-3.2 \%$ (Albert et al., 1986). These values are lower than the obtained in our calculations, probably due to the different regional settings in Italy and in Gran Canaria.

The oxygen isotope trend has been interpreted as a cooling trend (Chafetz and Lawrence, 1994; Kele et al., 2008). Therefore, the two main processes affecting isotopic fractionation downstream are progressive $\mathrm{CO}_{2}$ degassing and cooling. Although evaporation has been proposed as the main factor controlling oxygen isotope fractionation (Chafetz and Lawrence, 1994), we did not consider it as an important factor because the $\delta^{18} \mathrm{O}$ increasing trend is displayed by both, gorge bottom and perched systems. Perched systems have many springs along the gorge, and the $\delta^{18} \mathrm{O}$ trend indicates that whatever the fractionation process was, it took place within the aquifer. A cooling trend from Doramas Volcano to the sea along the gorge seems to be more accurate however evaporation effects are not discarded.

The $\delta^{18} \mathrm{O}$ values generally increase downstream due to changes in water composition and temperature, but also due to $\mathrm{C}$ speciation $\left(\mathrm{H}_{2} \mathrm{CO}_{3}, \mathrm{HCO}_{3}^{-}, \mathrm{CO}_{3}^{-2}\right)$ controlled by $\mathrm{pH}$ variations (Kele et al, 2008). The architectural evolution of these deposits and changes in vent position can also produce variations in these general trends (Chafetz and Lawrence, 1994).

\subsection{Water paleotemperature calculations}

We tentatively calculate the possible range of water temperature. Halas and Wolacewicz (1982) equation was used assuming that $\delta^{18} \mathrm{O}$ of vent travertine corresponds to the $\delta^{18} \mathrm{O}$ of $\mathrm{HCO}_{3}^{-}$dissolved in water (Kele et al., 2011). Thus, we used a $\delta^{18} \mathrm{O}$ value of $-11.32 \%$ (PDB), equivalent to $+19.37 \%$ ( (SMOW), obtained in the vent (feeder channels) facies. The Halas and Wolacewicz (1982) equation was calculated for calcite, so the oxygen isotope fractionation between calcite and aragonite has to be included (Zheng, 1999). We have obtain three different $\Delta\left(\mathrm{HCO}_{3}\right.$-water $)$ : uncorrected, and considering the minimum $(+0.6 \%)$, and the maximum $(+2.26 \%)$ oxygen isotope fractionation reported in literature (Zhou and Zheng, 2006). Because of the Azuaje travertines 

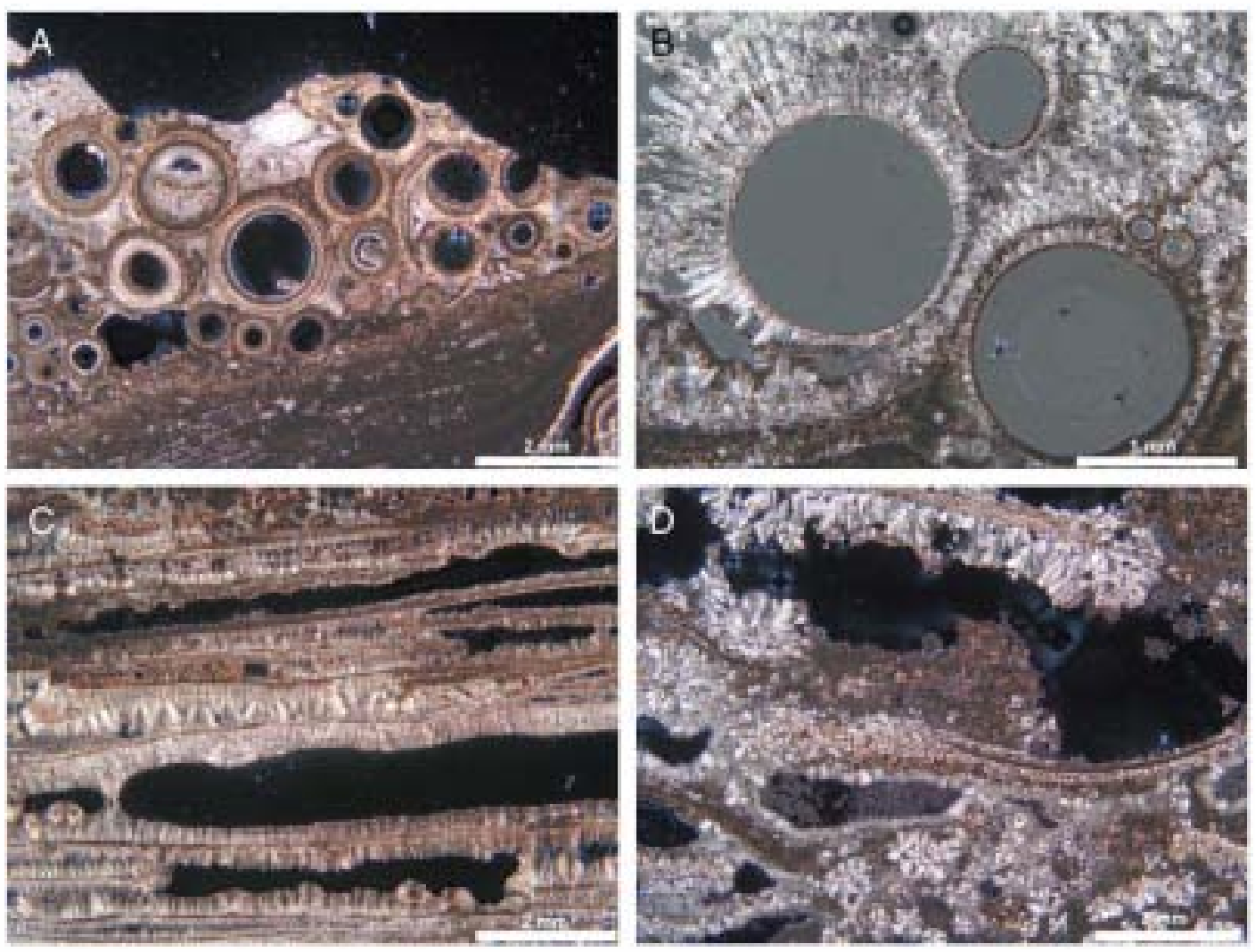

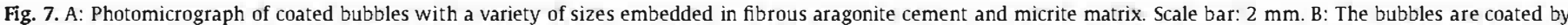

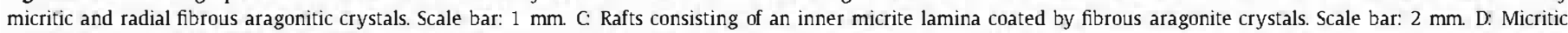
rafts showing coarse undulous calcite crystals on their undersides. Scale bar: $2 \mathrm{~mm}$.

are fossil we used $\delta^{18} \mathrm{O}$ values of present waters $(-5.5$ to $-3 \%$ SMOW) in the area.

The lower temperature range $\left(40-54{ }^{\circ} \mathrm{C}\right)$ was obtained using the maximum correction, whereas the higher range $\left(53-69^{\circ} \mathrm{C}\right)$ corresponds to the uncorrected value.

The lower temperature range seems to be the most accurate according to the observed facies, as indicated by the presence of diatoms which are common in geothermal floras whose temperature is below $45{ }^{\circ} \mathrm{C}$ (Owen et al, 2008). Nevertheless, a high degree of uncertainty is involved in these calculations because (i) present day $\delta^{18} \mathrm{O}$ water values are not necessarily the same than those at ravertine deposition time; (ii) only one vent sample was available; (iii) no oxygen isotopic shift between water and host rock was considered; (iv) paleogroundwater chemistry is unknown and different compositional effects affecting the isotopic fractionation could happened (Zhou and Zheng, 2006). Water temperature calculations, as is previously exposed, agree with these estimations of temperature.

\subsection{Aragonite versus calcite occurrence}

The presence of aragonite within ravertines is common, although calcite seems to be more common (Jones and Renaut, 1996; Kele et al., 2008). It is stll unclear why aragonite precipitation is favored in some surface environments, especially in some travertines. Temperatures above $40{ }^{\circ} \mathrm{C}$ have been invoked to explain the aragonite occurrence (Jones and Renaut, 2010) instead of calcite; however, calcite precipitation above even $90{ }^{\circ} \mathrm{C}$ has been reported (Jones and Renaut, 1995), and aragonite precipitation has been found in low temperature continental settings, such as Castañar Cave (Martin-Garcia et al., 2009). Therefore the temperature at spring outlets could have been higher than $45{ }^{\circ} \mathrm{C}$, but due to downstream cooling were lower in most of the travertine system. Thus, temperature could controlled the aragonite precipitation, but probably other factors, such as level of super-saturation or high $\mathrm{Mg} / \mathrm{Ca}$ rates, could have play a major role (De Choudens-Sanchez and González, 2009). The present day springs remaining in the area show high $\mathrm{rMg} / \mathrm{rCa}$ ratios (where $r$ denotes miliequivalents per liter), higher than 1 (Hemandez-Quesada, personal communication). Therefore, this situation could have been occurred during travertine deposition times.

\subsection{Biogenic versus abiogenic precipitation}

With respect to the mechanisms of precipitation, two main aspects are considered: the role of microbes and the common occurrence of fibrous aragonite with radial crystals. Many of the facies recognized in the Azuaje travertine have been interpreted both as biogenic and abiogenic precipitates. Such is the case of shrubs (Chafetz and Guidry, 1999), coated bubbles, and coated grains (Chafetz and Folk, 1984; Chafetz et al., 1991). Microscopic observations in samples from Azuaje reveal the presence of some biological features such as micron-size tubules or diatoms. However, these biogenic features are relatively scarce, except in the porous facies, either because they were initially scarce or because they have not been preserved. Whatever the case the fibrous aragonite textures show very few biogenic features. Jones and Renaut (2010) interpreted fibrous calcite aggregates as produced by precipitation in strong disequilibrium, which may be caused by sudden $\mathrm{CO}_{2}$ degassing. The abrupt release of $\mathrm{CO}_{2}$ causes an increase of $\mathrm{pH}$ and controls the $\mathrm{C}$ speciation $\left(\mathrm{H}_{2} \mathrm{CO}_{3}, \mathrm{HCO}_{3}^{-}, \mathrm{CO}_{3}^{-2}\right)$, favoring super-saturation (Kele et al, 2008) and leading to isotope fractionation. The overall morphology of most of the aragonite aggregates and crystals of the Azuaje travertine, some of its facies (coated bubbles), and the carbon isotopic values all strongly support the idea of aragonite precipitation under non-equilibrium conditions and suggest that the main travertine-forming process was abrupt degassing of thermogenic 

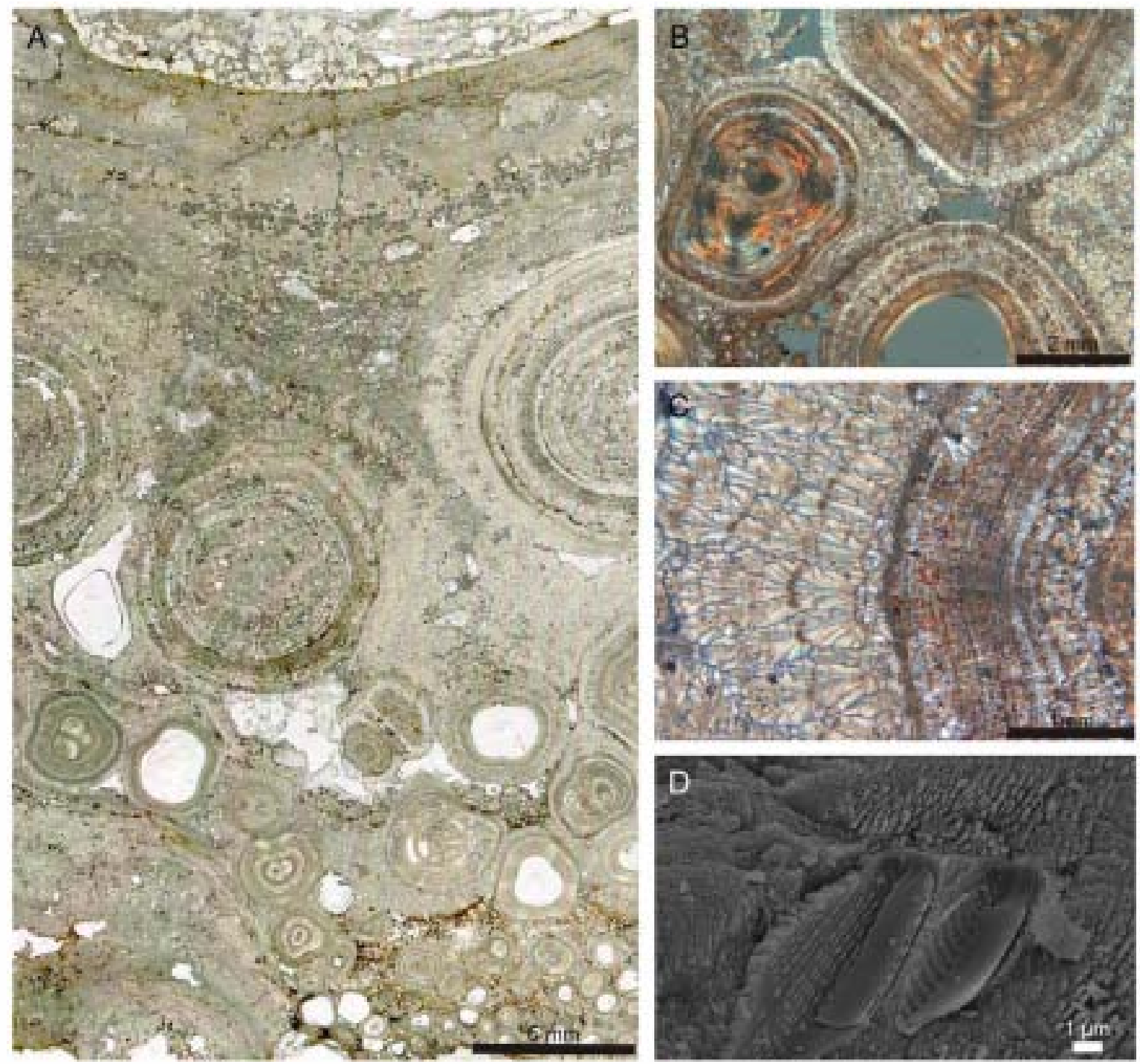

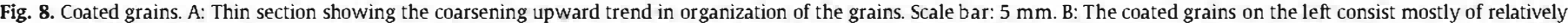

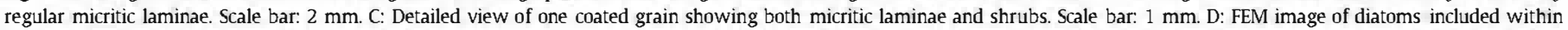
the coated grains.

waters related to the volcanic event that erupted the lava flow on the floor of the Azuaje Gorge.

\section{Conclusions}

The Azuaje ravertine formed after the last volcanic event which produced a lava flow along the floor of the Azuaje Gorge about 2500 years ago. Travertine deposits are very rare in the Canary Islands and only small deposits have been found, also related to recent volcanic activity. The Azuaje deposit consisted of two morpho-depositional systerns: (1) perched systems on gorge walls and (2) gorge bottom deposits oriented parallel to the modem stream. Perched systems include: aragonite tabular crusts interpreted as feeder channels, and waterfall and barrier deposits. Gorge bottom deposits also include barriers and pool deposits.

Aragonite is the main mineral making up the travertine, however the variety of facies and microfacies is high, and includes: tabular aragonitic crusts, laminar facies (coarse crystalline, fibrous or micritic), porous facies, and a variety of features such as shrubs, coated grains, coated bubbles and rafts. Many of these facies are composed of fibrous aragonite crystals formed under disequilibrium conditions caused by rapid $\mathrm{CO}_{2}$ degassing. This mechanism may explain the rapid super-saturation of waters that led to aragonite precipitation. At the spring outlets the waters could have been at a temperature of around $40{ }^{\circ} \mathrm{C}$ favoring aragonite precipitation instead of calcite. The isotope values especially the carbon isotope data, are similar to those found in thermogene traverthes that formed in waters of thermal origin. Cooling of waters is recorded in the increase of the $\delta^{13} \mathrm{C}$ and $\delta^{18} \mathrm{O}$ values downstream, but also aragonite is still the main precipitate downstream, so other factors, apart from temperature, such as $\mathrm{Mg} / \mathrm{Ca}$ ratios or degree of super-saturation have to be considered to explain the aragonite composition of the Azuaje travertine. Microbial precipitation could also have played a minor role, as some organic features have also been found and some of the microfacies have been interpreted to have been biogenically mediated.

\section{Acknowledgements}

This work was funded by projects CGL-2011-27826-C02-01 from the Spanish Ministerio de Ciencia e Innovación and CCG07-UCM/ AMB2299 from CM-UCM. J. Cerne reviewed the English version of the manuscript. Special thanks to the reviewers, S. Kele and an anonymous one, for their suggestions and comments. 


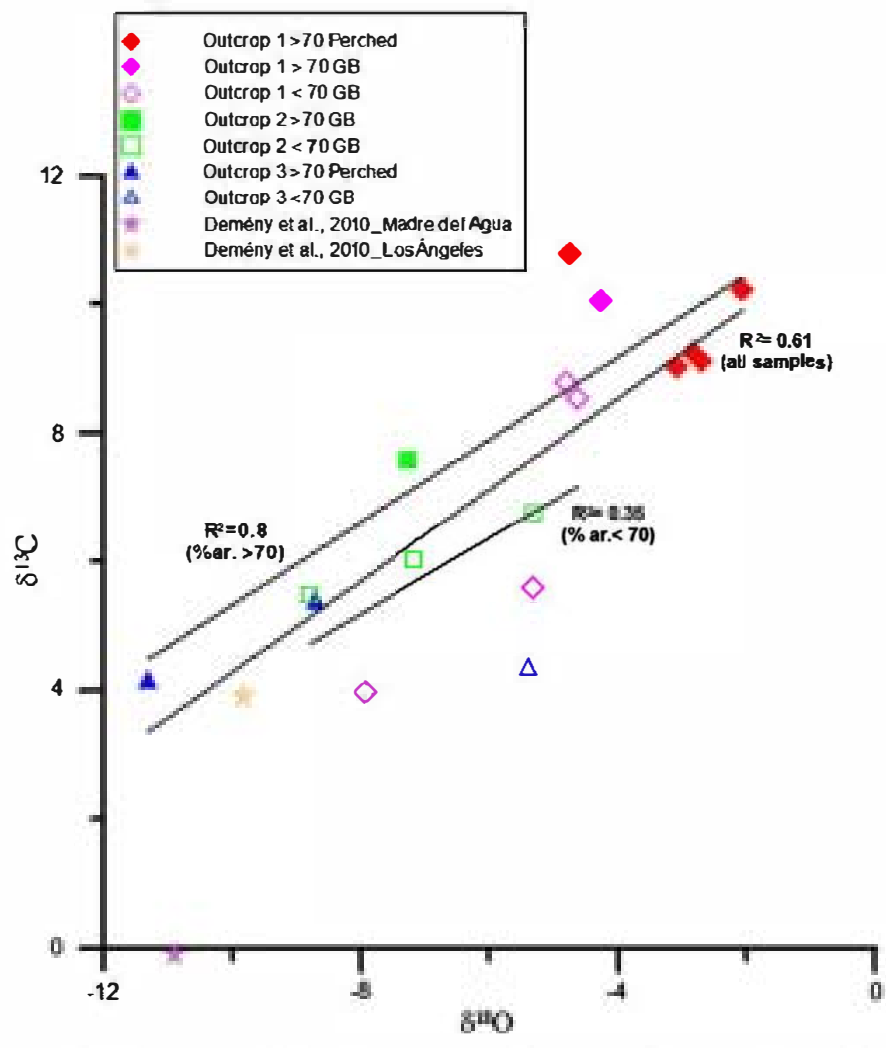

Fig. 9. Stable oxygen and carbon isotope composition of the Azuaje travertine samples. Aragonite content is represented by filled symbols $(>70 \%)$ and unfilled symbols $(<70 \%)$. GB: gorge bottom deposits; P: perched deposits.

\section{References}

Albert, J.F., Araña, V., Diez, J.L., Filly, A y, Fontes, J.Ch, 1986. Modelo termodinámico de la actividad del Teide. Anales de física. Serie B: Aplicaciones, métodos e instrumentos 82, 86-201 (especial).

Andrews, J.E., 2006. Palaeoclimatic records from stable isotopes in riverine tufas: synthesis and review. Earth-Science Reviews 75, 85-104.

Anzalone, E., Ferreri, V., Sprovieri, M., D'Argenio, B., 2007. Travertines as hydrologic archives: the case of the Pontecagnano deposits (southern Italy). Advances in Water Resources 30, 2159-2175.

Carracedo, J.C., Pérez-Torrado, F.J., Ancochea, E., Meco, J., Hernán, F., Cubas, C.R., Casillas, R., Rodríguez-Badiola, E., 2002. Cenozoic volcanism: II the Canary Islands. In: Gibbons, F.A.W., Moreno, T. (Eds.), The Geology of Spain: Geological Society, London, pp. 438-472.

Chafetz, H.S., Folk, R.L, 1984. Travertines: depositional morphology and the bacterially constructed constituents. Journal of Sedimentary Petrology 54, 289-316.

Chafetz, H.S., Guidry, S.A, 1999. Bacterial shrubs, crystal shrubs, and ray-crystal shrubs: bacterial vs. abiotic precipitation. Sedimentary Geology 126, 57-74.

Chafetz, H.S., Iawrence, J.R., 1994. Stable isotopic variability within modern travertines Géographie physique et Quaternarie 48, 257-273.

Chafetz, H.S., Meredith, J.C., 1983. Recent travertine pisoliths (pisoids) from Southeastern Idaho, USA. In: Peryt, T.M. (Ed.), Coated Grains. Springer-Verlag, Berlín, pp. 450-455.

Chafetz, H.S., Rush, P.F., Utech, N.M., 1991. Microenvironmental controls on mineralogy and habit of $\mathrm{CaCO}_{3}$ precipitates: an example from an active travertine system. Sedimentology 38, 107-126.

Custodio, E., 2007. Groundwater in volcanic hard rocks. Groundwater in fractured rocks. In: Krásný, J., Sharp Jr., J.M. (Eds.), Selected Papers no s: International Association of Hydrogeologists. Taylor \& Francis, Iondon, pp. 95-108.

D'alessandro, W., Giammanco, S., Bellomo, S., Parello, F., 2007. Geochemistry and mineralogy of travertine deposits of the SW flank of Mt. Etna (Italy): relationships with past volcanic and degassing activity. Journal of Volcanology and Geothermal Research 165, 64-70.

De Choudens-Sanchez, V., González, L.A., 2009. Calcite and aragonite precipitation under controlled instantaneous supersaturation: elucidating the role of $\mathrm{CaCO}_{3}$ saturation state and $\mathrm{Mg} / \mathrm{Ca}$ ratio on calcium carbonate and polymorphism. Journal of Sedimentary Research 79, 363-376.

Demény, A., Kele, S., Siklósy, Z., 2010. Empirical equations for the temperature dependence of calcite-water oxygen isotope fractionation from 10 to $70^{\circ} \mathrm{C}$. Rapid Communications in Mass Spectrometry 24, 3521-3526.

Ford, T.D., Pedley, H.M., 1996. A review of tufa and travertine deposits of the world. Earth-Science Reviews 41, 117-175.
Fouke, B.C, Famer,J.D., Des Marais, D.J., Pratt, L, Sturchio, N.C., Burns, P.C., Discipulo, M.K 2000. Depositional facies and aqueous-solid geochemistry of travertine-depositing hot springs (Angel Terrace, Mammoth Hot Springs, Yellowstone National Park, U.SA.). Joumal of Sedimentary Research 70, 565-585.

Freytet, P., Verrecchia, E.P., 1998. Freshwater organisms that build stromatolites: a synopsis of biocrystallization by prokaryotic and eukaryotic algae. Sedimentology $45,535-563$.

Frisia, S., Borsato, A., 2010. Karst. In: Alonso-Zarza, A.M., Tanner, L.H. (Eds.), Facies Environments and Processes. Elsevier, Amsterdam, pp. 269-318.

Gandin, A., Capezzuoli, E., 2008. Travertine versus calcareous tufa: distinctive petrologic features and stable isotopes signatures. Italian Journal of Quaternary Sciences 21, 125-136.

Gasparini, A., Custodio, E., Fontes, J.C. Jimenez, J., Nuñez, J.A, 1990. Exemple d'etude geochimique et isotopique de circulations aquiferes en terrain volcanique sous climat semi-aride (Amurga, Gran Canaria, lles Canaries). Journal of Hydrology 114,61-91

Guillou, H., Perez Torrado, F.J., Hansen Machin, A.R., Carracedo, J.C., Gimeno, D., 2004 The Plio-Quaternary volcanic evolution of Gran Canaria based on new K-Ar ages and magnetostratigraphy. Journal of Volcanology and Geothermal Research 135 221-246.

Guo, L., Riding, R., 1998. Hot-spring travertine facies and sequences, Late Pleistocene, Rapolano Terme, Italy. Sedimentology 45, 163-180.

Halas, S., Wolacewicz, W., 1982. The experimental study of oxygen isotope exchange reaction between dissolved bicarbonate and water. Journal of Chemical Physics 76, 5470-5472.

Hankock, P.L., Chalmers, RM.L., Altunel, E., Gakir, Z., 1999. Travitonics: using travertines in active fault studies. Journal of Structural Geology 21, 903-916.

Hernandez-Quesada, P., Cabrera, M.C., Custodio, E., 2011. Características y evolución de los nacientes en las cuencas de los barrancos de Azua je y Moya, Norte de Gran Canaria. In: Cabrera, M.C., Jiménez, J., Custodio, E. (Eds.), El conocimiento de los recursos hídricos cuatro décadas después del proyecto SPA-15. Homenaje póstumo al Dr. Ingeniero D. José Sáenz de OizAsociación Internacional de HidrogeólogosGrupo Español, Las Palmas de Gran Canaria (Spain), pp. 73-79.

Jones, B., 2009. Cave Pearls-the integrated product of abiogenic and biogenic processes Journal of Sedimentary Research 79, 689-710.

Jones, B., Renaut, R.W., 1995. Noncrystallographic calcite dendrites from hot-spring deposits at Lake Bogoria, Kenya. Journal of Sedimentary Research A65, 154-169.

Jones, B., Renaut, R.W., 1996. Morphology and growth of aragonite crystals in hot-spring travertines at Lake Bogoria, Kenya Rift Valley. Sedimentology 43, 323-340.

Jones, B., Renaut, R.W., 2010. Calcareous spring deposits in continental settings. In: Alonso-Zarza, A.M., Tanner, L.H. (Eds.), Carbonates in Continental Settings. Facies Environments and Processes. Elsevier, Amsterdam, pp. 177-224.

Kano, A., Fuji, H., 2000. Origin of the gross morphology and internal texture of tufas of Shirokawa Town, Ehime Prefecture, southwest Japan. Journal of the Geological Society of Japan 106, 397-412

Kele, S., Vaselli, O., Szabó, C, Minissale, A., 2003. Stable isotope geochemistry of Pleistocene travertine from Budakalász (Buda Mts, Hungary). Acta Geologica Hungarica 46, 161-175.

Kele, S., Demény, A., Siklósy, Z, Németh, T., Mária, T., Kovács, M.B., 2008. Chemical and stable isotope compositions of recent hot-water travertines and associated thermal waters, from Egerszalók, Hungary: depositional facies and non-equilibrium fractionations. Sedimentary Geology 211, 53-72.

Kele, S., Özkul, M., Fórizs, I., Gökgöz, A., Baykara, M.O., AIçiçek, M.C., Németh, T., 2011. Stable isotope geochemical study of Pamukkale travertines: new evidences of low temperature non-equilibrium calcite-water fractionation. Sedimentary Geology 238 191-212.

Keppel, M.N., Post, V.E.A. Love, A.J., Clarke, J.D.A., Werner, A.D., 2011. Influences on the carbonate hydrochemistry of mound spring environments, Lake Eyre South region, South Australia. Chemical Geology 296-297, 50-65.

Martín-Algarra, A. Martín-Martín, M., Andreo, B., Juliá, R., Gozález-Gómez, C., 2003. Sedimentary patterns in perched spring near Granada (Spain) as indicators of the paleohydrological and paleoclimatological evolution of a karst massif. Sedimentary Geology 161, 217-228.

Martín-García, R., Alonso-Zarza, AM., Martín-Pérez, A, 2009. Ioss of primary texture and geochemical signatures in speleothems due to diagenesis: evidences from Castañar Cave, Spain. Sedimentary Geology 221, 141-149.

McCrea, J.M., 1950. On the isotope chemistry of carbonates and paleotemperature scale. Journal of Chemical Physics $18,849-857$.

Melezhik, V.A, Fallick, A.E., 2001. Paleoproterozoic travertines of volcanic affiliation from a ${ }^{13} \mathrm{C}$-rich rift lake environment. Chemical Geology $173,293-312$

Menéndez, I., Silva, P.G., Martín-Betancor, M., Pérez-Torrado, F.J., Guillou, H., Scaillet, S., 2008. Fluvial dissection, isostatic uplift, and geomorphological evolution of volcanic islands (Gran Canaria, Canary Islands, Spain). Geomorphology 102, 189-203.

Minissale, A, 2004. Origin, transport and discharge of $\mathrm{CO}_{2}$ in central Italy. Earth-Science Reviews 66, 89-141.

Mook, W.G., 2001. Environmental isotopes in the hydrological cycle. Principles and application IHP_V Technical Documents in Hydrology, $\mathrm{n}^{\circ}$ 39. UNESCO-IAEA.

Nader, F.H., 2007. Petrographic and geochemical study on cave pearls from Kanaan Cave (Lebanon). International Journal of Speleology 36, 39-50

Ostermann, M., Sanders, D., Prager, C., Kramers, J., 2007. Aragonite and calcite cementation in "boulder-controlled" meteoric environments on the Fern Pass rockslide (Austria): implications for radiometric age dating of catastrophic mass movements. Facies 53 189-208.

Owen, R.B., Renaut, R.W., Jones, B., 2008. Geothermal diatoms: a comparative study of floras in hot spring systems of Iceland, New Zealand, and Kenya. Hydrobiologia $610,175-192$ 
Panichi, C.. Torgiorgi, E., 1976. Carbon isotopic composition of $\mathrm{CO}_{2}$ from springs, fumaroles, mofettes and travertines of central and southern Italy: a preliminary prospection method of geothermal area. Proc. 2nd UN Symp. On the Develop and Use of Geotherm Energy, 20-29 May 1975, San Francisco, U.S.A, pp. 815-825.

Pedley, M., 1990. Classification and environmental models of cool freshwater tufas. Sedimentary Geology 68, 143-154

Pedley, M, González Martín, J.A., Ordoñez Delgado, S., García del Cura, M.A, 2003. Sedimentology of Quatenary perched springline and paludal tufas: criteria for recognition, with examples from Guadalajara Province, Spain. Sedimentology 50, $23-44$

Pentecost, A, 1993. British travertines: a review. Proceedings of the Geologists' Association $104,23-39$

Pentecost, A, 2005. Travertine. 445 pp. Springer, Berlín.

Pentecost, A, 2012. Some observations on travertine algae from Stjáni hot spring Lýsuhóll, Iceland. Nordic Journal of Botany 29, 741-745.

Rainey, D.K. Jones, B, 2009. Abiotic versus biotic controls on the development of the Fairmont Hot Springs carbonate deposit, British Columbia, Canada. Sedimentology $56,1832-1857$.

Renaut, R.W., Jones, B., 1997. Controls on aragonite and calcite precipitation in hot spring travertines at Chemurkeu, Lake Bogoria, Kenya. Canadian Journal of Earth Sciences 34, 801-814

Rodriguez-Gonzalez, A., Fernandez-Turiel, J.L, Perez-Torrado, F.J, Hansen, A, Aulinas, M., Carracedo,J.C., Gimeno, D., Guillou, H., Paris, R. Paterne, M. 2009. The Holocene volcanic history of Gran Canaria Island: implications for volcanic hazards. Journal of Quaternary Science 24,697-709.

Rodriguez-Gonzalez, A, Fernandez-Turiel, J.L, Perez-Torrado, F.J, Paris, R., Gimeno, D. Carracedo,J.C., Aulinas, M., 2012. Factors controlling the morphology of monogenetic basaltic volcanoes: the Holocene volcanism of Gran Canaria (Canary Islands, Spain) Geomorphology 136, 31-44.

Sanders, D., Wertl, W., Rott, E., 2011. Spring-associated limestones of the Eastern Alps: overview of facies, deposystems, minerals and biota. Facies 57, 395-416.
Schreiber, B.C., Smith, D., Schreiber, E., 1981. Spring peas from New YorkState: nucleation and growth of fresh water hollow ooliths and pisoliths. Journal of Sedimentary Petrology 51, 1341-1346.

Szulc, J., Gradzinski, M., Lewandowska, A., Heunisch, C., 2006. The Upper Triassic crenogenic limestones in Upper Silesia (southern Poland) and their paleoenvironmental context. In: Alonso-Zarza, AM, Tanner, LH. (Eds.), Paleoenvironmental Record and Applications of Calcretes and Palustrine Carbonates. Geological Society of America, Special Paper 416, 153-168.

Taylor, M.P., Drysdale, R.N., Carthew, K.D., 2004. The formation and environmental significance of calcite rafts in tropical tufa-depositing rivers of northern Australia. Sedimentology 51, 1089-1101.

Valero-Garcés, B.L. Arenas, C., Delgado-Huertas, A., 2001. Depositional environments of Quaternary lacustrine travertines and stromatolites from high-altitude Andean lakes, northwestern Argentina. Canadian Journal of Earth Sciences 38, 1263-1283.

Vázquez-Urbez M Arenas, C. Pardo, G, 2012. A sedimentary facies model for stepped, fluvial tufa systems in the Iberian Range (Spain): the Quaternary Piedra and Mesa valleys. Sedimentology 59, 502-526.

Viles, H.A. Pentecost, A. 2007. Tufa and Travertine. In: Nash, D.J., Mclaren, S.J. (Eds.), Geochemical Sediments and Iandscapes. Blackwell Publishing Ltd., Oxford, pp. 173-179.

Yoshimura, K., Liu, Z., Cao, J., Yuan, D., Inokura, Y., Noto, M., 2004. Deep source $\mathrm{CO}_{2}$ in natural waters and its role in extensive tufa deposition in the Huanglong Ravines, Sichuan, China. Chemical Geology 205, 141-153.

Zamarreño, I., Anadón, P., Utrilla, R., 1997. Sedimentology and isotopic composition of Upper Palaeocene to Eocene non-marine stromatolites, eastern Ebro Basin, NE Spain. Sedimentology 44, 159-176.

Zheng, Y.F., 1999. Oxygen isotope fractionation in carbonate and sulfate minerals Geochemical Journal 33, 109-126.

Zhou, G.T., Zheng, Y.F., 2006. On the direction and magnitude of oxygen isotope fractionation between calcite and aragonite at thermodynamic equilibrium. Aquatic Geochemistry $12,239-268$. 